\title{
Reprinted Before Publication: Plotting a Route for Sans Everything
}

Barbara was belligerent with her press campaign. She enthused the press to enlighten the public and to pave the way for Sans Everything. Anne Robinson recalled:

I can remember one report, one story where I didn't have the space to put in all she wanted.... The edition went at six o'clock, she turned up at the Sunday Times at about four to argue it in, on Saturday afternoon. ${ }^{1}$

In early 1967, the Ministry began to prepare for an outburst of public opinion in response to Sans Everything and for the fuss it anticipated that AEGIS (Aid for the Elderly in Government Institutions) would continue to make. The Ministry did not regard the allegations with the gravity that Rolph had hoped for, in terms of triggering high-level public investigations. ${ }^{2}$ Plans emerged to hold nonstatutory, private inquiries established by Regional Hospital Boards (RHBs).

Sans Everything exploded into the headlines on 30 June 1967. The same day, Ten O'Clock, a BBC radio current affairs programme interviewed Barbara, and 24 Hours, a $\mathrm{BBCl}$ television news programme, featured Sans Everything. With anticipated high demand for the book, the publisher reprinted it before publication. ${ }^{3}$ Sans Everything achieved best-seller status in the first week. ${ }^{4}$ One reader, Mabel Franks, wrote to Barbara comparing her to Francis Chichester who returned from his solo circumnavigation of the globe in May 1967:

(C) The Author(s) 2017

C. Hilton, Improving Psychiatric Care for Older People, Mental Health in Historical Perspective, DOI 10.1007/978-3-319-54813-5_5 
I consider your achievement far more commendable than that of Chichester. Granted he is a very brave man and we all admire his courage, but your courage is of a noble kind for it will benefit humanity in the future.... You had the guts and moral fibre to pursue this matter and bring it right into the open. ${ }^{5}$

\section{The Press Paves the Way}

Guardian journalist Ann Shearer argued the importance of the press in publicising scandals. The press has to answer the question: 'Is it in the public interest to publish or to keep quiet?' If it is in the public interest, the press can provide information that puts people who want to see change in touch with those who are in a position to make it happen: 'the freedom of the press to put uncomfortable situations before the electorate is an essential element in the assumptions on which our societies are run. And if the media did not fulfil this role, who would?' Based on her personal experience of seeking to improve psychiatric hospitals and the responses she received from the authorities, Shearer (1976, p. 112) wrote: 'it would be naïve to leave it to "those who know best," those most involved.'

Rolph introduced Barbara to reporters and editors on several national newspapers, including the Daily Mail, Sunday Telegraph and News of the World. Barbara compiled dossiers for them, and in return they provided 'much assistance'. ${ }^{6}$ According to Rolph (1987, p. 184) 'editors in Fleet Street... never saw manuscripts so overwhelmingly supported by authority, and never had to feel uneasy about any statement Barbara made.' Editors trusted Barbara with their, and their newspapers', futures: libel, slander or unethical information could precipitate disrepute, a legal case or a hearing by the Press Council, the public body that aimed to maintain high standards of journalism. The Press Council had no concerns about Barbara's well-backed-up allegations, but it approached Kenneth Robinson in 1966, about secretiveness and the press's poor relationship with the NHS. Despite official agreements for NHS press releases, editors complained of varying standards of information 'particularly in the matter of accidents and that sometimes there appeared to be a desire to restrict disclosure of hospital affairs beyond the point of public good'. Robinson retaliated that, on occasions, the press published 'exaggerated or distorted reports' (Press Council 1966, pp. 8-9). The Press Council complaints files were destroyed, ${ }^{7}$ precluding chances of confirming the circumstances and evidence behind its exchange with Robinson. The Council's concerns, 
however, matched Richard Crossman's (1977, p. 134): ' $O$ of one thing I'm sure. The public relations of the Ministry of Health are terrible. It has an appallingly bad press office and really faulty relations with the general public.' One newspaper editor no longer sent reporters to RHB meetings because the only part of the proceedings that they witnessed was the Board operating 'simply as a rubber stamp meeting' (Fortune 1967). RHBs had the right to exclude press and public from parts of meetings for which they deemed that publicity 'would be prejudicial to the public interest'. The North West Metropolitan (NWM) RHB demonstrated this sort of exclusion when it discussed a circular from the Ministry about ill-treatment in psychiatric hospitals, although whether their exclusion was justified is unclear from the minutes. ${ }^{9}$ Around the same time, Conservative MP Kenneth Lewis asked Robinson in Parliament how many RHBs allowed the press to attend their meetings. Robinson replied, 'All', without further explanation, ${ }^{10}$ an emphatic but reassuring half-truth.

More reports of inadequate and custodial psychiatric care appeared in the national press and bolstered AEGIS's argument. In March 1967 the Times reported accidents causing the deaths of two elderly patients on an overcrowded ward of a psychiatric hospital (Leamington Spa reporter 1967). The same month, the BBC screened a documentary, What Shall We Do with Granny? It questioned whether any institution was an appropriate place to care for men and women who had lived independent lives for fifty or sixty years, let alone a crowded, bleak dormitory in a psychiatric hospital or former workhouse (BBCl, 1967).

Several newspapers and periodicals took up the Sans Everything theme before its publication. The Sunday Times, Nursing Mirror and News of the World showed particularly consistent support for the AEGIS campaign. Hugo Young was chief leader writer of the Sunday Times, which had a circulation of 1.5 million copies each week (Monopolies 1985). On 4 June, coinciding with Mental Health Week and three weeks before the publication of Sans Everything, Young cited extensively from two of the reports due to appear in the book (Young 1967). He criticised the nursing structure and the lack of training, particularly of 'people deceptively entitled "nursing assistants" whose training is only a tepid and hasty dilution' but praised the work done by nurses, 'unsung and unrewarded... among the most admirable heroes of medicine'. He alleged that complaints by staff or patients about standards of care could lead to reprisals against them. Lively debate followed in the correspondence columns, largely 
supporting Young's message. John Andrews (1967), nurse tutor at Claybury Hospital, wrote that psychiatric hospitals needed 'regular articles such as yours'. Applebey (1967) supported the idea of an inspectorate for all institutions where chronically ill or disabled people lived, not just for psychiatric hospitals, and if the government was unwilling to set this up, then the National Association for Mental Health (NAMH) would gladly do so if given the resources. Others added their personal knowledge about the effects of overcrowding and underfunding. A few correspondents criticised Young's article: some condemned the nurses whose accounts he cited, and one, Sir Ivor Julian (1967), chairman of the South East Metropolitan RHB, rebutted Young's argument.

The Nursing Mirror, read widely by nurses but not by the general public, announced Sans Everything two weeks before publication. The editor, Yvonne Cross, wrote that she felt privileged to have read it in advance: 'privileged in humility and shame, for we have known something of these conditions and have been powerless to do anything to help the nurses who have reported them to us.' An editorial (Anon. 1967a) invited readers' comments on three questions: Would you complain forcibly to your superior about malpractice or appalling conditions? If the complaint did not achieve its objectives, would you pursue the matter? Would you feel confident that you would survive discredit and materially alter the situation? The Nursing Mirror printed the first answers on 23 June (Anon. 1967c): one student nurse wrote that to go above her immediate superior, 'to pursue the matter further would be unethical, and strictly against the conduct of a good nurse', indicating her understanding of the importance of obedience in the profession. Every letter expressed fear of reprisals, and many nurses would not take that risk.

Cross also wrote directly to Robinson after the Ministry made a press release that rebutted Young's statement in the Sunday Times that staff and patients were fearful of speaking out: ${ }^{11}$

You are mistaken in your rejection of the suggestion that reprisals are used against nurses who rebel publicly against sick administration in hospitals. There are thousands of ways in which nurses and patients can be made to pay dearly if they dare to raise their voices in criticism... I believe this book to have created the opportunity for which thousands of people have been waiting, and...I intend to support it from the pages of the journal-and in every other way open to me. ${ }^{12}$ 
Other journalists argued similarly, that Fleet Street's support for AEGIS reflected a collective guilt about an issue of which it was distantly conscious but that had been kept under wraps (Cochrane 1990, p. 75). Concerning reprisals towards staff who spoke up, when Nigel Fisher MP asked Robinson if he would give 'protection of anonymity to anyone who comes forward with the evidence' Robinson replied: 'Yes, certainly', but he gave no clues as to how he could, or would, do that. ${ }^{13}$ His uncertainty reflected reality when, a few months later, the Ministry nebulously instructed RHBs to try to 'dispel such apprehensions'. ${ }^{14}$

A third publication that offered consistent support to AEGIS was the News of the World, a Sunday newspaper, which, in the 1960s, had an enormous circulation of about 6 million copies a week (Rogers 2011). Their journalist, David Roxan, was familiar with mental hospitals and injustices of compulsory detention. In 1956 he worked with the National Council for Civil Liberties to secure the discharge of Peter Whitehead, who was inappropriately detained in mental hospitals for twelve years. Roxan's book, Sentenced without Cause (1958), described stripping Whitehead of his belongings and personal identity on admission (pp. 96-101), physical violence by staff to patients on the wards (p. 147) and difficulty securing Whitehead's discharge against the wishes of the authorities (p. 254), all detrimental processes resembling those that AEGIS uncovered. William Williams MP commented in 1958 that 'everybody' except the Ministry agreed that Peter Whitehead's detention was wrong. The Ministry, then under Conservative Party leadership, defended mental hospital practices, criticised Roxan's book as sensational and irresponsible and said that his attack on hospital practices was 'unjust' because staff, 'often under trying conditions, carry out their duties with sympathy and devotion and precious little thanks from the public'. ${ }^{15}$ Lomax (1921), Roxan (1958) and Barbara (1967a) identified similar inhumane practices, and the Ministry rejected the allegations each time. Royal Commissions, Aneurin Bevan and others revealed difficulties in the mental hospitals, but ideas and intentions from the Ministry, Boards and hospital leadership did not match the commitment that would be necessary to ensure change. Overall, the Ministry indicated its conviction that psychiatric hospitals were fit for purpose (Rogers and Pilgrim 1996, pp. 58-71).

Roxan approached Barbara to offer his support and first cited her evidence in May 1966. Roxan (1966) also quoted COHSE, the Confederation of Health Service Employees trades union, to which many psychiatric nurses belonged. ${ }^{16}$ Similar to the message Tooth gave 
to Barbara, ${ }^{17}$ COHSE stated, according to Roxan's article: 'There are hospitals where things do happen and there is little the Ministry can do about it.' This apathetic view ignored the possibility that COHSE could improve work conditions for its members if it encouraged the Ministry to provide better patient care. Roxan also quoted Applebey: 'People may not know it but we have a major problem on our hands', and a Ministry spokesman: 'much is being done' but 'we are very much aware' that more is needed. According to Abel-Smith, the Ministry's comments were NHS jargon, similar to labelling services as 'continuously under review', all of which meant that no further action was required (Stewart and Sleeman 1967). ${ }^{18}$ Responding to Roxan's article, a care home matron (Anon. 1966) described her difficulties of finding staff: 'The staffing in old folks' homes has never been so bad. Hours are long, pay is bad-and we superintendents and matrons have almost to accept anything on two legs as staff.' On 25 June 1967, Roxan's eye-catching report, titled 'Old folk beaten in hospital', gave details of the 'startling allegations' in Sans Everything, due to be published the following Friday. He also wrote that the 'usually conservative' Royal College of Nursing (RCN) upheld the allegations (Roxan 1967a).

\section{The Ministry, Robinson and the Press: Planning Inquiries}

The independent inquiry into the Aberfan disaster, the colliery tip landslide in 1966 that killed 116 children and 28 adults, was fresh in the mind of the public. It found

a terrifying tale of bungling ineptitude by many men charged with tasks for which they were totally unfitted, of failure to heed clear warnings and of total lack of direction from above. Not villains, but decent men, led astray by foolishness or ignorance or by both in combination, are responsible for what happened (Welsh Office 1967, p. 25).

The inquiry blamed the Coal Board, the statutory authority that ran the nationalised coal mining industry, revealing its inept management of matters for which it was responsible and accountable (Welsh Office 1967, p. 131). The broader implication was that public bodies could be negligent. The enormous publicity around Aberfan gave the public some knowledge of inquiry processes that were also relevant to the planning, procedures and disputes associated with Sans Everything. Inquiries are 
'inquisitorial' - that is, the inquiry committee is actively involved in investigating the facts of the case, as opposed to an 'adversarial' process in which the role of the court is primarily that of an impartial referee between the prosecution and the defence. Inquiries seek to establish the facts and provide a full and fair account of what happened, especially in circumstances where evidence is disputed or the course and causation of events is unclear. Other functions include catharsis for those involved; learning in order to prevent a recurrence; and reassurance that the government is making sure the issue is fully dealt with. These aims, however, are not always entirely compatible with a single process. Public inquiries may be the best for reassurance, but an inquiry undertaken in private may be the best to determine the truth. The political need to provide reassurance that the situation will not recur drives the need to find simple causative factors, which risks blaming front-line staff, such as nurses, and diverting attention away from failures of senior management which are less visible. Finding a scapegoat can relieve rage and frustration, which is one reason witnesses need legal representation to ensure justice for themselves (Howe 1999).

The Royal Commission on Tribunals of Inquiry (1966) established principles for managing inquiries. It recommended that in 'circumstances which occasion a nation-wide crisis of confidence' inquiries should be established by Parliament (p. 16). For the NHS, that meant instituting an inquiry under section 70 of the NHS Act 1946. Legislation in $1967^{19}$ brought section 70 under the jurisdiction of the Council on Tribunals, an advisory public body set up in 1958 to ensure that inquiries were run according to high standards, including being open, fair and impartial: open, for publicity of proceedings and the reasoning behind decisions; fair, through having a clear procedure, including allowing participants to present their case fully; impartial, by ensuring independence from the real or apparent influence of the authorities (Administrative Tribunals 1957, p. 10). ${ }^{20}$ Procedures to achieve a comprehensive analysis of events included having an independent chairman who could enforce the attendance of witnesses, take evidence on oath and compel the production of documents. The Ministry identified only six instances between 1948 and 1966 when it used section 70 inquiries. All were disputes relating to employment, building works and finances. ${ }^{21}$ None related directly to patient care or treatment. It is hard to believe that no patient-focussed serious or unresolved NHS complaints warranted section 70 inquiries during these years. One explanation for this absence was that the Ministry gave complaints only cursory attention. 
In February 1967, Robinson met with Tooth and other civil servants, to plan how to investigate the Sans Everything allegations. He proposed that 'the desire to protect staff from allegations of brutality and cruelty might be the spur to action' and that this could stem either from a parliamentary question or a request from COHSE, which would want to protect its members. ${ }^{22}$ Bernard Braine MP supported the concept of inquiries 'to restore public confidence', ${ }^{23}$ which, like Robinson's aim to protect staff, implied that the allegations were false, a perspective that did not bode well for impartial committees of inquiry to approach their task open-mindedly. Robinson was also determined that Barbara should receive no credit for the outcome: "the setting up of an Enquiry had to look convincingly spontaneous, and not as if he was being pushed into it by people such as Mrs Robb. ${ }^{24}$

The Ministry was uncertain about procedures and legal matters, reinforcing the impression that it lacked experience in processing complaints. It was ambivalent about instigating inquiries because it usually delegated complaint management to the RHBs. Removing that role could be interpreted as the Ministry assuming that the RHBs lacked the necessary skills, suggesting little trust or openness for negotiation between them. The Ministry also considered how it should respond to the Mental Health Act (1959, section 126), which stated that it was a criminal offence to 'ill-treat or wilfully neglect' a patient 'receiving treatment for mental disorder' in a psychiatric hospital. That included unintentional but reckless practices. The Ministry decided to avoid mentioning the offence because it might deter witnesses from giving evidence. ${ }^{25}$ Ignoring the law was a surprising course of action for a government department. The Ministry's legal specialist advised against using section 70 , on the basis that the allegations were probably unsound rather than serious, ${ }^{26}$ further evidence that the authorities pre-judged them. The Ministry also rejected a section 70 inquiry because the allegations related to several regions and that separate inquiries 'were no less independent but merely less cumbersome' than a single inquiry. ${ }^{27}$ Robinson prioritised practicalities over principles, imprudent for legal processes.

In April 1967, Maurice Miller, a medically qualified Labour MP, asked Robinson an 'inspired' parliamentary question, whether 'existing methods of dealing with complaints that elderly patients, particularly in psychiatric hospitals, are ill-treated, afford adequate protection for patients and staff'. Robinson replied, reassuringly, 'Yes', referring to the complaints guidance circulated the previous year and with the implication that the Ministry 
could confidently deal with the issues. The parliamentary question conveniently provided Robinson with the opportunity to praise staff and to announce a loophole for not investigating Sans Everything: 'General unsubstantiated allegations are impossible to pursue and cast unfair suspicion on all those, doctors, nurses and others, who devote themselves to the care of these patients. ${ }^{28}$

The Ministry received a prepublication copy of Sans Everything on 20 June. An internal memo commented: 'There is little in the book which is new' and 'It is reasonable to assume that Mrs Robb is making as damaging a case as she can from the information she has received. ${ }^{29}$ The first comment admitted that the Ministry knew about the problems. If that was the case, why did it try to give the impression that all was well, ${ }^{30}$ rather than try to improve the situation? The second implied malicious intent on Barbara's part. The memo recommended that the Ministry should make a statement to refute Barbara's evidence, emphasising that she withheld permission for it to be used in 1965. However, one reason she withheld permission was because she had lost confidence in the Ministry's ability to investigate (Strabolgi et al. 1965). ${ }^{31}$ Months of discussion at the Ministry in 1967 about how to investigate, supported Barbara's contention.

\section{Publication Day: 30 June 1967}

The presenter of Ten O'Clock, Mr Hunt, interviewed Barbara. He asked her, 'Which do you regard as the most brutal of your allegations?' She avoided being dragged into specific witch-hunt type questions and replied that physical brutality was scarce: 'What concerns me... is the atmosphere in so many of the geriatric wards and the traumatic effect that this has on the patients.' When Hunt challenged her on why the nurses did not speak out, she defended them and explained their fear of reprisals. Hunt criticised her 'emotionally toned words', such as using the word stripping, to which she replied that she first heard it at the Ministry from a senior official, 'a very unemotional gentleman-a very charming gentleman', 32 Dr Tooth. Hunt said that emotional language might have weakened her case: the authorities did not appreciate passion or drama about a cause, or acknowledge that emotive language could indicate the complainant's desperation about the situation.

Presenters Cliff Michelmore and Kenneth Allsop probed the story on 24 Hours. ${ }^{33}$ Silhouettes and voices of the nurse-authors Davie, Daniel and Moodie reiterated their accounts in Sans Everything. Film shots 
taken at St Peter's showed Amy and Barbara chatting. Cross's succinct responses supported Barbara and the nurses. Cross reinforced the need to investigate hospitals rather than individuals and that nurses feared reprisals. When Michelmore challenged her about why ex-nurses did not complain, she replied: 'How much credence would you give, say, an ex-television producer, who came and said "terrible things went on in my studio when I was there five years ago"?... being an ex-anything immediately reduces your case.'

Allsop interviewed Robinson, allowing him the final word. Robinson said he would investigate if he received sufficient evidence. However, Robinson defended the NHS, and reiterated his confidence in the system: 'I am absolutely sure, that the care of our old people in our geriatric and psychiatric hospitals is as good as anything in the world.' It was ironical to make such a comment, which lacked corroboration, ${ }^{34}$ in the context of criticising AEGIS for its unsubstantiated evidence. He said he wanted to investigate the allegations, but was concerned that, eighteen months after the events 'the trail is getting cold', indicating his concern about identifying individual wrong-doers. Allsop, reiterating Cross's point, challenged him on this focus on incidents, rather than on investigating a general malaise in the hospitals, but Robinson stuck to his plan.

The press picked up on Robinson's apparent lack of knowledge, or denial, of poor care in hospitals and his attitude to the allegations. The Sunday Mirror criticised Robinson, who, 'to his shame, seemed to pooh-pooh [Sans Everything] on Twenty-Four Hours' (Allen 1967). The BBC received a 'flood' of letters. Some people objected to the programme repeating the criticisms made in Sans Everything. Some complained about anonymising hospitals and silhouetting interviewees. However, many more thought the $\mathrm{BBC}$ was right to bring the matter into the open. Some letter writers recounted their experiences in hospitals, as patients, staff or visitors. One nurse, who wrote that her ward sister told her to 'sling' a patient in the bath even if she didn't want one, complained to matron, was ostracised by staff and left the hospital. She said: 'I was getting tough, hard-hearted, I had lost my individuality...I had lost the kindly world I belonged to.' A son wrote about his elderly mother's care. She spent the last four months of her life in hospital: she was stripped, had falls and sustained three fractures. He suspected that lack of supervision contributed to her falls, but when he enquired about whether there would be an inquest, he was told that little could be done 
about his concerns. ${ }^{35}$ The 24 Hours programme also outraged Barbara's Aunt Missie:

When Mr Robinson said there was no truth in the 'Diary of a Nobody'... I cried out: 'He is calling me a liar'. I can indeed vouch that the facts ... [were] told to me as they occurred. And I am ready to swear before any 'enquiry' as to Amy Gibb's wonderful good health and normality when I spent the afternoon with her at the convent. ${ }^{36}$

After the programme, Cross sent Robinson letters received by the Nursing Mirror to back up her statement about nurses fearing reprisals. ${ }^{37}$ Robinson's private secretary replied:

The Minister is much disturbed at the letters which report reluctance on the part of nurses to press complaints to the hospital authorities for fear of reprisals, or belief that even if they reported such things, no improvement would result. He feels that this is as much a matter for the nursing profession itself to deal with as for him, and senior officers of the Department have already discussed this with the President of the Royal College of Nursing. ${ }^{38}$

Robinson externalised the problem away from the authorities, towards the nurses themselves. In total, 250 nurses wrote to the Nursing Mirror. Many nurses would speak out if they thought it would lead to improved practice, but, as Cross reflected two years later, 'the painful truth is that, invariably, their own discredit is the only result of their efforts' (Anon. 1969).

Support for AEGIS manifest in surprising ways, such as a shift in the allegiance of the NAMH away from officialdom. Chief Nursing Officer Kathleen Raven noted a 'rather unpleasant' outcome of Sans Everything: Applebey sung Barbara's praises at a sherry party at the King's Fund, claiming that 'the campaign about Sans Everything would not have had the same effect if the NAMH had not helped to produce it.' Raven continued, that the Ministry contributed significantly to NAMH funds, ' $£ 10,000$ per annum and paying expenses for health service employees to attend their annual conferences', a veiled threat of sanctions if NAMH continued side with AEGIS. ${ }^{39}$ In October 1967 NAMH published a booklet to promote understanding of the mental health needs of older people. It opened with the words: 'When face to face with an elderly person, often sans eyes and sans ears, and nearly always sans teeth, it is 
tempting to wonder what this ageing man or woman might have been like as a little boy or girl' (Emery 1967, p. 1). Following so soon after Sans Everything, it is likely that the booklet and the words were inspired by it. AEGIS's campaign was also a factor leading to NAMH adopting a more forceful, lobbying stance (NAMH 1969, pp. 5-7; Long 2014, pp. 177-178).

\section{After Publication: Secrecy, Privacy and Confidentiality}

Barbara's concern about confidentiality and safety of witnesses was admirable. However, with the publicity given to Sans Everything, complete confidentiality was unrealistic. It was inevitable that people involved, and the hospitals subject to investigation, would become known locally. ${ }^{40}$ This happened on the day of publication. Sir Arnold France, Permanent Secretary at the Ministry, noted that in Leeds 'staff at the hospital are talking amongst themselves... it may become public knowledge that Sister Biss is thought to be the nurse in question. It might get to the ears, of course, of opposition Members of Parliament. ${ }^{41}$ It is interesting that he centred his worries on political tactics rather than on staff or patients.

The stream of letters from staff, patients and their relatives, to AEGIS, the Ministry, Patients Association (PA), NAMH, and the press, indicated widespread hospital problems. The Ministry received 186 negative letters about the care of older people in about 100 different hospitals. A 'considerable number' of people addressed their letters personally to Robinson. The Ministry drew up 'special arrangements' to deal with the letters, to guide staff as to which required replies from the Ministry, which should be forwarded to the RHBs, and which the RHBs should investigate and then feed back to the Ministry. ${ }^{42}$ Psychiatrists working with mentally unwell older people, such as David Enoch and Garry Blessed, trying to do their best in their own hospitals, corroborated that it was a matter of 'there but for the grace of God go I. ${ }^{43}$ Publicly naming the hospitals in Sans Everything risked scapegoating them and detracting from the wider significance of the proposed inquiries, reinforcing Barbara's stand on maintaining confidentiality for hospitals and witnesses. ${ }^{44}$

The Ministry lacked a clear strategy about how to define, distinguish and manage the potentially conflicting issues of 'secrecy', 'privacy' and 'confidentiality' in the context of inquiries. ${ }^{45}$ Barbara kept the press informed about progress on these matters (Anon. 1967f, 1967g). The 
Ministry's lack of clarity, however, added to Barbara's reservations about a level playing field for the proposed inquiries. In September, the Ministry apologised to her for not explaining its intentions more clearly. 'S6 'Secrecy' could lead to leaks and provoke press comment, ${ }^{47}$ antagonise the public and affect the credibility and outcome of an inquiry (Anon. 1967e). It might, for example, prevent potential witnesses from giving evidence if they did not know of an inquiry's existence. On the other hand, 'privacy' for individuals to give evidence could increase their willingness to disclose information. 'Confidentiality' was relative in government terms. The Ministry argued, 'In confidence in its widest sense would have effectively prevented the setting up of any Enquiry ${ }^{38}$ and that 'in confidence' had to be interpreted in the light of an inquiry's findings, including the possibility of subsequent criminal proceedings. ${ }^{49}$ The Ministry was also under obligation to publish a report, as Patrick Gordon-Walker, minister without portfolio, had undertaken to do so during a Commons debate. ${ }^{50}$ Robinson understood that this would include hospital names. ${ }^{51}$ In the same debate, Robinson made an obtuse remark, probably indicating his irritation with Barbara: he praised a female MP for opening the debate 'in a way that was generally constructive and, if I may say so, unsensational'. ${ }^{52}$

Mr RS Matthews, Robinson's private secretary, wrote to Barbara. In a well-reasoned letter, he acknowledged her policy of publishing pseudonymously to avoid scapegoats but encouraged her to identify the complainants, patients and staff to enable a full inquiry. He pointed out that proposals made by Abel-Smith in Sans Everything (1967, pp. 128-135) about investigating complaints were practical only if specific incidents were identified. Alternatively, Matthews suggested, Barbara could reveal the hospital names 'in confidence', which would enable 'independent investigations' to be made into the situation at those hospitals, even if the individual incidents could not be examined. Matthews' letter ended: 'The contents of this letter are being released to the Press.' By return post, Barbara asked Matthews to define an independent investigation. He replied that Robinson 'would arrange for enquiries to be carried out by a legally qualified chairman from outside the National Health Service, probably assisted by other persons unconnected with the hospital concerned'. ${ }^{53}$ Satisfied with Matthews' reply, she contacted the authorwitnesses for permission to disclose details, and awaited their replies.

With consent from the author-witnesses, Barbara revealed the hospitals' names, in confidence, as the Ministry asked. ${ }^{54}$ However, in the light of a Commons debate on 11 July, her caution was justified. Contrary to the 
earlier promise that Robinson would establish the inquiries, he announced that the RHB chairmen would undertake that task. ${ }^{55}$ This change had huge implications. If Robinson appointed the committees, on behalf of Parliament, the inquiries would be overseen by the Council on Tribunals, but delegating the task to the RHBs removed this protection. Barbara was horrified: she revealed the names of the hospitals on the understanding that Robinson would set up inquiries. She described the change as a 'breach of faith'. 56

Despite the RHBs appointing the committees, the author-witnesses agreed to give evidence and for their names to be disclosed to the chairmen. ${ }^{57}$ Barbara remained concerned that RHB-appointed committees would inhibit nurses from criticising their own hospitals because of fear of reprisals, ${ }^{58}$ and that because the RHBs were taking charge of evaluating their own performance, the committees could not be impartial. Barbara's view could be justified based on her previous experience of Blofeld's inquiry, taking into account that she never received the report. The Ministry was convinced that RHB-appointed committees would be 'completely impartial', 59 although their appointment contradicted the Council on Tribunals' principles of ensuring independence from real or apparent influences of the authorities. On this point, Barbara was particularly concerned about the Friern committee, for which the RHB proposed to appoint Isabel Graham Bryce as the lay member. Graham Bryce was chairman of Oxford RHB and therefore could not be 'lay' in the Ministry's definition of someone 'who should represent predominantly the view of the patient'. ${ }^{60}$ More specifically, the Oxford Mail published a statement from the Oxford RHB, "that the allegations made in a recent issue of a National Sunday newspaper did not apply to their hospitals' (Anon. 1967b). Barbara assumed that a published RHB report would have the chairman's 'knowledge and acquiescence' and that because the statement was incorrect the chairman's dishonesty would prejudice her inquiry role. The Ministry consulted Hackett about Graham Bryce's appointment. Hackett was sure that the statement in the Oxford Mail provided no grounds to replace her and that 'this move on the part of Mrs Robb is primarily designed to obstruct the inquiry'. ${ }^{61}$ Crossman later described Graham Bryce as 'a mere stooge', ${ }^{62}$ although he was also condescending towards other RHB chairmen, describing them as insignificant creatures trying to do a bit of public service and really entirely dominated by their officials'. ${ }^{63}$ 
The Sunday Times published a letter from Hackett, 'Hospitals: we are experts'. He wrote:

A great deal of harm is being done to the Health Service by the book Sans Everything, with the brutal and scaring headlines in newspapers and on TV. This dreadful book will not give us one more pair of hands-what is worse, it may well cause us to lose many nurses and others, tired and disillusioned with the apparent lack of public appreciation of the work they do (Hackett 1967).

The day before Hackett's letter appeared, the Times published a statement made by Phyllis Rowe at a nursing conference. She said that no member of the RCN psychiatric committee denied the validity of the 'ghastly material' in Sans Everything and the book provided a 'wonderful opportunity for psychiatric nurses to see what could be done' (Anon. 1967d). Hackett had incorrectly assessed the nurses' mood, and his condemnation contradicted Rowe. AEGIS's careful groundwork with the RCN was bearing fruit. Like Cross, ${ }^{64}$ Rowe reflected on a sense of guilt in the profession for not having acted sooner (Anon. 1967d). Letters in the Sunday Times the following week criticised Hackett and NHS managers who did not know, or try to find out, about abuse in their hospitals. Barbara's letter stated: 'In view of Mr Hackett's evident tendency to prejudge these issues, the public will surely be hoping that he is not one of the regional board chairmen being asked by the Minister to set up "independent" inquiries into circumstances in their own hospitals' (Robb 1967b).

Hackett discussed with Robinson whether any inquiry was needed at Friern because Blofeld's was 'searching' and the RHB interpreted it that 'no evidence of cruelty or ill treatment was found.' ${ }^{65}$ Hackett and Robinson agreed that another inquiry was unnecessary but gave way to avoid the risk that they would 'be accused of having something to hide'. 66 Robinson was impatient to start the inquiries and to avoid more 'unfruitful correspondence' with Barbara. ${ }^{67}$

\section{Other Responses in the Public Arena}

Many people wrote to Barbara, often distraught. ${ }^{68}$ Other letters from voluntary bodies asked for AEGIS's support or advice. ${ }^{69}$ Supporters and admirers also wrote. Portrait sculptor Beth Jukes sent Barbara a photograph of her bronze torso sculpture of a thin, stooped, wrinkled, naked 
elderly woman staring down at her hands folded in her lap, called Sans Everything. ${ }^{70}$ The Nursing Mirror reviewed Sans Everything, saying it was constructive despite generalisations and anonymisation and encouraged nurses to read it: nurses needed to acknowledge that bad conditions existed in some hospitals, especially where patients were the most helpless and that nurses needed to speak out (Greene 1967). A review in the Catholic paper, the Tablet described Sans Everything as 'case material for Dickens, Kingsley or Ruskin' with 'Pilate-like washing of hands at all stages in the hierarchy from nurse to member of hospital board' (Russell 1967). Allen (1967), in the Sunday Mirror, wrote that Barbara was 'the author of the year's most challenging book'. Allen adopted another religious analogy, the parable of the 'Good Samaritan', calling her article 'One woman who refused to pass by..'.

Some major medical journals drew attention to Sans Everything. Psychiatrist Tom Arie (Anon. 1967h) in the Lancet, did not question the validity of the reports and praised the suggestions of 'radical innovation' to improve the situation. ${ }^{71}$ In the $B M J$, geriatrician Eluned Woodford-Williams (1967) recognised the authenticity of the reports, and the challenges:

Aid for the Elderly in Government Institutions has as its aim to shame the Government... into doing something about the cruelty and neglect which is the lot of many of our aged citizens.... The danger is that the lack of facts may enable it to be too easily dismissed, for those who have worked with the aged know that there is some truth in the accusations.

James Mathers (1968), a psychiatrist in Birmingham, wrote: 'let us not pretend that we think that Sans Everything (even if exaggerated) was an unjustified publication and that anyway it is no responsibility of the doctors.'

The British Journal of Psychiatry did not publish a review, despite the book's emphasis on psychiatric hospitals. Neither did Gerontologia Clinica, a leading journal of geriatric medicine that Woodford-Williams edited. The absence of reviews in both of these was surprising. Reasons for their absence could have been because the journals were not offered the book to review or it might relate to difficulties finding a reviewer, taking into account lack of interest of many geriatricians in the goings-on of mental hospitals (Denham 2004) and of many psychiatrists in undertaking clinical work with older people (Fine 1963). Some psychiatrists also 
objected to Barbara, as an outsider, interfering in service-related matters, and some geriatricians objected to the lack of mention in Sans Everything about good geriatric services that increasingly existed in general hospitals (Felstein 1969, pp. 9-11). ${ }^{72}$

Some RHBs had good intentions about improving conditions for older people. Manchester RHB (Mackay and Ruck 1967) investigated their needs. Its report, published internally, was logical and innovative such as proposing 'that long stay patients should have the best accommodation in a hospital rather than the worst' because, as their permanent home, it should be as pleasant as possible and favourable conditions promoted older people's independence and reduced disability (p. 9). The RHB proposed to address the report's concerns 'as opportunity occurs' and 'as their resources permit' (pp. 5-6), but an open-ended promise, amid competing priorities, was unlikely to succeed. The laissez-faire approach risked neglecting the report in the same way as the wards and people it sought to assist: 'dumping grounds, the patients becoming chronic discards' (p. 19). SK Ruck, one of the researchers, wrote to Barbara, attributing renewed interest in his work to Sans Everything: 'I'm half inclined to wonder whether it would have seen the light of day but for your book, since it has lain "incommunicado" with the RHB for more than a year since it was written. ${ }^{, 73}$ The Times commented that the Manchester report: 'confirms, in rather more official language, many of the more startling disclosures' in Sans Everything (Northern Correspondent 1967). Commissioned by the NHS, the Manchester study had respectability and authority, but lacking priority it risked neglect, reinforcing the need for dedicated pressure groups for unpopular social issues.

The media, according to Hackett, failed to provide the statutory authorities with an opportunity to present their side of the Sans Everything argument to the public, even though Robinson was prominent on 24 Hours on 30 June. Hackett wanted a second 24 Hours programme in which he could 'confront Mrs Robb'. He approached the BBC to arrange it. $^{74}$ Whether Hackett's request contributed to the BBC's decision to produce a second programme is unclear, but the BBC enlisted him and Abel-Smith as the 'experts' for the programme.

The programme began with Allsop recapping on the Sans Everything issues, then interviewing people who had witnessed abuse, this time facing the cameras. The interviewees included a nurse and three relatives whose reports were uncomfortably close to the allegations described in Sans Everything: uncooperative staff, unkindness to patients and an elderly 
woman who was slapped for being incontinent. Abel-Smith commented on how to improve NHS complaints procedures, especially the need for independent inquiries. Allsop then asked Hackett for his comments, in the context of his recent Sunday Times letter, 'Hospitals: we are experts'. Hackett overlooked the essence of the question and answered by finding fault with the Sunday Times editor and promoting his own skills: 'the headline you just quote about being experts wasn't mine. The one I put was a much better one but the papers altered it.' With prompting by Allsop to achieve a relevant answer, Hackett was unhesitant: there was no need to change the complaints procedures, of course the RHBs would investigate properly, 'we are on the side of the patient. That is what we are there for.' Abel-Smith retorted: 'You might as well say that the Chairman of the Coal Board should be appointed to investigate the Aberfan Disaster.' Hackett followed the plan Robinson stated in the previous 24 Hours, aiming to find individuals at fault. With names of the hospitals, he said, 'we can investigate the cases of cruelty'. In contrast, Abel-Smith focused on principles and had the last word: 'Mrs Robb is fighting for a principle, the principle of totally independent inquiries and she is going to win the battle. What she wants is an inquiry set up right outside the hospital service and we don't normally get it. ${ }^{75}$

\section{'Smouldering Discontent' Elsewhere}

Just before publication of Sans Everything, the Ministry wrote to chairmen of all RHBs instructing senior staff to make 'searching enquiries' to ensure that there were no grounds for complaints in their hospitals. The letter was worded to prompt the reply that all was well. ${ }^{76}$ RHBs obtained data from HMCs and fed back to the Ministry, but not all reports were positive. Clare Turquet and Stella Brain ${ }^{77}$ wrote about provision in the South West Metropolitan region. They doubted that 'physical cruelty could go long unchecked', but 'harsh and unsympathetic treatment, and some lessening of the dignity of the individual elderly patients, may well be accepted in the wards'. They noted other problems, including boredom, and patients not encouraged or allowed to wear spectacles, hearing aids or dentures, from which they might benefit. They concluded: 'Whether the distressing incidents [Sans Everything] sets out are substantiated, or not...we all know in our hearts that there are still very bad conditions in some of our hospitals. ${ }^{78}$ 
Other HMCs reassured their RHBs that malpractice did not happen in their hospitals (DHSS 1972, p. 8). ${ }^{79}$ However, as a direct result of the publicity around Sans Everything, a staff member at Ely Hospital in Cardiff and nursing students at Whittingham Hospital in Lancashire, revealed discontent and concerns about standards of care in their hospitals (DHSS 1972, pp. 7-8). ${ }^{80}$

When the Welsh Hospital Board (WHB, with the iconic address 'Temple of Peace and Health', Cardiff) sought feedback from its HMCs, the HMC responsible for Ely Hospital replied:

We are, of course, assured by the senior officers...that there is no inhumanity in the treatment of patients, particularly elderly patients, and if the number of complaints which are made direct to the Committee or myself is a yardstick, we can feel assured that this is so.... We have a system of monthly rota visits by members.... All these reports state that there were no complaints from the patients or staff. ${ }^{81}$

By the time the HMC sent this summary to the WHB, Roxan had forwarded to the Ministry a report about scandalous practices at Ely that he received following his article about Sans Everything in the News of the World (Roxan 1967a). ${ }^{82}$ This report was one of five sent to Roxan, all of which outlined situations similar to those in Sans Everything. Each report gave the informant's name and address and identified the hospital. With the authors' agreement, Roxan sent the reports to the Ministry. For the Ministry, the report from Michael Pantelides, an assistant nurse at Ely, stood out. Allegations included violence towards patients, lies by staff about injuries, and pilfering of patients' food (also found at Storthes Hall). ${ }^{83}$ The Ministry cautiously criticised the informant but did not deny the contents. An official wrote:

This is an astonishing document and quotes names lavishly. Moreover it gives the names of 3 other nurses willing to give evidence.... There is a danger that $\mathrm{Mr}$ Pantelides is a man with a grievance making reckless allegations and that his 3 witnesses will not support him but nevertheless I do not think that anything but an independent enquiry would be satisfactory. ${ }^{84}$

The Ministry feared that if it neglected the reports, Roxan would put pen to paper and discredit Robinson's sincerity about seeking improvements. The Ministry sought guidance from its legal advisors on how to proceed. ${ }^{85}$ 
In August, the News of the World published anonymised summaries of the reports (Roxan 1967a, 1967b). Because this was during the parliamentary summer recess, there could be no anticipatory Commons discussion or conveniently planted or inspired questions to minimise their impact.

Ely, a hospital for 'mentally subnormal' people, rather than for psychiatric illness, had wards for children and adults. The HMC inspection reports were usually brief, about half a page, and suggest cursory scrutiny, particularly focused on the physical environment and lacking discussion with staff or patients, as was typical of that sort of inspection (Barton 1959, p. 48). Nevertheless, the reports changed markedly after 1960. In the early 1960s, the HMC generally approved of what they saw and praised the staff, including how the nurses cared for patients. The positive became interspersed with minor criticisms and then, with a marked change in tone, to clear concern. In March 1965, one report noted that 'Every effort should be made to reduce the overcrowding in this hospital, urgently.' In October 1965, 'The staffing situation is deteriorating and calls for urgent attention' and gave suggestions how to ameliorate it. The HMC visitors also noted, on one ward, one toilet for forty-five patients. In 1967, attempts were made to upgrade the wards, but planning was poor and did not meet needs: 'The day rooms are very small and some ambulant patients must remain in bed until after dinner as there is not sufficient space for them to sit and eat. ${ }^{86}$ Shockingly, around 1965, the Ministry inspected Ely and found scandalous conditions: a deplorable report 'had gone on file' at the Ministry without any intervention (Crossman 1977, p. 411). ${ }^{87}$ The Ely HMC did not respond to early warnings of dysfunction in the hospital, similar to responses at Friern and Storthes Hall.

The events at Ely matched AEGIS's concern that planned inspections were ineffective and that number of complaints as a measure of quality was inaccurate. Pantelides left Ely having 'found the atmosphere uncomfortable' because colleagues were hostile towards him. ${ }^{88}$ An inquiry into the happenings there followed the Sans Everything inquiries but had significantly different outcomes. This is taken up again in Chapter 7 (pp. 214-222), after discussion of the Sans Everything inquiries.

As at Ely, events at Whittingham Hospital unfolded because of Sans Everything. In July 1967, 'smouldering discontent among the student nurses caught alight' when forty-five student nurses met with the senior nursing tutor (DHSS 1972, p. 7). The tutor proposed to discuss patient care 'in relation to recent Press statements ... arising from the publication Sans Everything' (p. 52). The students alleged dangerous and demeaning 
practices: patients struck with a key strap, put to bed too early in the evenings, locked in the coal-house or bathroom, tormented for the amusement of staff and bathed with long mops when incontinent. Although there was some safety in numbers, as punishing all the students would draw attention to problems at the hospital, the students feared retribution, especially if they reported individuals and specific incidents (pp. 52-53).

The tutor informed the chief male nurse about the allegations, and he called a second meeting, with the students, the tutor, matron and himself. Still fearful of victimisation, the students refused to particularise allegations (pp. 52-53). Subsequently, the three senior nurses met with the HMC chairman, to help answer the Ministry's letter about malpractice in their hospital, but they did not mention the students' complaints. The senior nurses made a few more attempts to obtain precise details of the students' allegations, but the students 'piped down'. The HMC was not informed of their concerns (p. 8). These events supported the notion that juniors feared making complaints and took their concerns only to their immediate seniors and that HMCs and RHBs could genuinely be unaware of the extent of problems in their hospitals.

In 1970, Barbara received more information about events at Whittingham, indicating long-term failure to deal with concerns, similar to Ely, Storthes Hall and Friern. Barton, for example, raised concerns there in 1965, but to no avail. ${ }^{89}$ After the conviction of a nurse for manslaughter of a patient kicked to death at Whittingham, Barton's conclusion was brief: 'Belsen had similar episodes.' 90

A committee of inquiry was appointed at Whittingham in 1971, under section 70 of the NHS Act (DHSS 1972, p. 1). Somebody-Barbara did not know who-sent her a copy of the report before publication. She ensured that summaries appeared in several national newspapers, pressing for publication of the full report and paving the way for more publicity to ensure improvements at Whittingham. ${ }^{91}$ The inquiry report found unacceptable practices mainly on long-stay back wards, the rest of the hospital practicing more therapeutically (DHSS 1972, pp. 1, 26). This underlined earlier concern about the two-tier, double standards in hospitals, providing better quality, rehabilitation-focussed psychiatric treatment, usually for younger people. Sir Keith Joseph (Secretary of State for Social Services, 1970-1974; Conservative government under Edward Heath) admitted after the Whittingham Inquiry that the government was not 'sufficiently alive to this danger' and was 'grappling' with it (Joseph 
1972, p. iii). Joseph's comment was surprising, suggesting ignorance at government level about long-standing discriminatory patterns of resourcing, staffing and facilities, such as at Claybury, Friern/Halliwick, and elsewhere (Jones and Sidebotham 1962, p. 62). ${ }^{92}$

\section{Comment}

Sans Everything stimulated more revelations of ill-treatment, indicated by the many letters sent to AEGIS, the Ministry, the NAMH, PA and BBC, and the press. AEGIS's links with the national press enabled timely and often prominent reports that highlighted the problems and indicated the value of investigative journalism in a campaign context. Sans Everything also stimulated established bodies, such as the RCN and NAMH, to become more involved with AEGIS's objectives and helped bring the constructive Manchester RHB study into the open.

AEGIS recognised common patterns of NHS dysfunction, including that deficits in care could be long-standing and that numbers of complaints and planned inspection visits were of dubious value in determining quality of provision. It also found that junior, new or inexperienced staff were often the whistle-blowers, and seniors and their peers generally responded unconstructively to their concerns. How to achieve a NHS culture that responds constructively to whistle-blowing remains a problem in the twenty-first century.

AEGIS masterminded the production of Sans Everything. It distributed copies of the book to significant people prepublication and enthused the press to announce when it would be available to the public. Sans Everything set out to shock. It did not just rant against the system, but proposed ways to make improvements, authoritatively backed by experts. The Ministry, however, grasped only the rant and repeatedly scapegoated Barbara for unnecessary, inappropriate and damaging publicity and time-consuming intrusions for which it had little patience. No evidence has come to light that the Ministry made any attempt to resolve AEGIS's concerns by face-toface meetings or that it considered changing its tactics in the light of mounting evidence. Enoch thought the NHS leadership 'didn't want to know, they didn't want to believe it. Nobody wanted to believe it. ${ }^{93}$ Rolph added that any serious inquiry 'won't be set off by Kenneth, you can bet your life on that' ${ }^{94}$ Labour MP Dennis Hobden wrote to Barbara: 'I long ago gave up [on] Kenneth Robinson. There has been nothing but evasion and covering up by Hospital Management Committees from top to 
bottom. ${ }^{95}$ Hobden, Rolph, Cross and 'Pertinax' (1967) all alleged government coverups and lying and that a culture of fear encouraged the silence of hospital nurses. The Ministry's filing of a damning inspection report about Ely and the sequence of events at Whittingham reinforced the notion that coverups happened at all levels of psychiatric hospital administration. Suspicion that the NHS sought to conceal its inadequacies was consistent with the Press Council's complaint in 1966, and with Robinson's and Hackett's defensiveness of the NHS and their hostility towards AEGIS, although their responses did not blind the press or public.

Robinson sometimes sounded genuinely incredulous that practices happened as described in Sans Everything or that staff and patients feared reprisals if they complained. To believe the allegations he said, 'would be to accept that there is ... a conspiracy against the patients, and especially the weakest and most helpless patients. Does anyone, do the authors of Sans Everything, does the editor of the Nursing Mirror, really believe this?" 96 He appeared unaware of the many who did. The Ministry's failure to deal dispassionately with complaints, its lack of knowledge about establishing inquiries and the absence of patient-focussed section 70 inquiries during the NHS's first eighteen years, reinforced impressions of the Ministry's disregard for patients and its institutional self-justification and defensiveness, if not a conspiracy.

Robinson stated his expectations of the proposed inquiries into the Sans Everything allegations when interviewed on 24 Hours. When asked, 'Are you satisfied that [poor care] has been reduced, now, almost to nonexistence?' Robinson replied, 'That is my belief and I hope that any enquiries we can make will bear that out. ${ }^{97}$ Incredulity in the upper echelons of government about the allegations remained the dominant mind-set: it would not encourage impartial inquiries. From the Aberfan Inquiry it was clear that statutory authorities could mismanage services and neglect their responsibilities to the point of disregard for human life. Whether committees of inquiry into the Sans Everything allegations could disengage from establishment self-righteousness and preconceptions about the excellence of the NHS remained to be seen.

\section{Notes}

1. Anne Robinson, interview by author, 2015 .

2. AEGIS meeting, 16 March 1967, 49, 53, AEGIS/1/20 (AEGIS archive, London School of Economics).

3. Frontmatter, Sans Everything, Robb 1967a. 
4. Robb, note, AEGIS/B/2.

5. Letter, Mabel Franks to Robb, July 1967, AEGIS/2/10.

6. Robb, 'Record of a campaign', vol 2, 84, AEGIS/1/2/A.

7. Tonia Milton, Independent Press Standards Organisation (IPSO), email to author January 2016.

8. 14 July 1968.

9. NWMRHB minutes, 17 July 1967, BM.354-5/67 (London Metropolitan Archives, LMA).

10. 'Regional Hospital Boards (The Press)', Hansard HC Deb 8 May 1967, vol 746 c. $143 \mathrm{~W}$.

11. Ministry of Health $(\mathrm{MoH})$ press service, 'Conditions of the elderly in hospitals'. 6 June 1967, MH150/349 (The National Archives, TNA).

12. Letter, Cross to Robinson, 9 June 1967, MH150/350 (TNA).

13. 'Mental Hospitals (Conditions)'. Hansard HC Deb 26 June 1967, vol 749 cc.69-70.

14. Letter, A France to RHBs, 28 June 1967, MH150/350 (TNA).

15. 'Rampton Hospital (Peter Whitehead)', Hansard HC Deb 14 March 1958, vol 584 cc.875-886.

16. They belonged to COHSE rather than the Royal College of Nursing $(\mathrm{RCN})$, the nursing trades union and professional body, because of the restrictions on mental nurses joining the RCN. COHSE merged with other unions 1993 to form UNISON.

17. Meeting, Robb and Tooth, 25 May 1965, AEGIS/1/1.

18. AEGIS meeting, 16 March 1967, AEGIS/B/2.

19. Tribunals and Inquiries (Discretionary Inquiries) Order 1967.

20. Other standards were being efficient, timely and accessible.

21. MoH, c.1966. list of section 70 inquiries, MH159/213 (TNA).

22. MoH, 'Meeting with the Minister', 21 February 1967, MH150/349 (TNA).

23. 'Mental Hospitals (Conditions)', Hansard HC Deb 26 June 1967, vol 749 cc.69-70.

24. MoH, 'Meeting with the Minister', 21 February 1967, MH150/349 (TNA).

25. Memo (illegible signature) to RS Matthews, 27 June 1967, MH150/350 (TNA).

26. Memo, JC Hales to 'Secretary' 4 July 1967, MH150/350 (TNA).

27. $\mathrm{MoH}$, Some notes in dealing with press inquiries, c. June 1968, para 4; 'Formal inquiries under S 70', c.1967, MH159/213 (TNA).

28. 'Elderly Patients (Complaints)', Hansard HC Deb 11 April 1967, vol 744 cc.172-173W.

29. Memo, Benwell to Hedley, 20 June 1967, MH150/350 (TNA). 
30. MoH, 'Meeting with the Minister', 21 February 1967, MH150/349 (TNA).

31. Letter, Robb to Strabolgi, 9 August 1965, AEGIS/7/12.

32. BBC Home Service, Ten O'Clock Programme of News and Current Affairs, 30 June 1967, transcript, AEGIS/1/6.

33. BBCl, 24 Hours, 30 June 1967, transcript, AEGIS/1/6.

34. See Chapter 3, p. 80.

35. BBCl, 24 Hours, 28 July 1967, transcript, AEGIS/1/6.

36. Signed statement, Ernestine Anne, 1967, AEGIS/2/7/B.

37. Letter, Cross to Matthews, 5 July 1967, MH150/350 (TNA).

38. Letter, Matthews to Cross, 12 July 1967, MH150/350 (TNA).

39. Memo, Kathleen Raven to Hedley, 13 July 1967, MH150/350 (TNA).

40. Letter, Matthews to Robb, 17 August 1967, MH159/220 (TNA).

41. Memo, France to Robinson, 30 June 1967, MHl50/350 (TNA).

42. Memos, 'Complaints about care of the elderly in hospital', July 1967, MHl50/350; Giddon to FDK Williams, November 1967, MHI59/220 (TNA).

43. Garry Blessed, letter, to author; David Enoch, interview by author, 2015.

44. Letter, Robb to Miss Nevin, South West Metropolitan (SWM) RHB, 22 August 1967, AEGIS/2/10.

45. Letters, Fanklyn Williams, Welsh Hospital Board to Croft, 27 September 1967; Geoffrey Howe to Robinson, 22 October 1967, MH159/221 (TNA).

46. Draft reply, Ministry to AEGIS's solicitors, 29 September 1967, MH159/ 220 (TNA).

47. Letters, Howe to Robinson, 22 October 1968, and reply, 6 November 1968, MH96/2198 (TNA).

48. Memo, Croft, 23 October 1967, MH159/220 (TNA).

49. Letter, LR Warner to AEGIS's solicitor, 8 September 1967, AEGIS/A/1.

50. 'Care of the elderly', Hansard HC Deb 11 July 1967, vol 750 cc.431-554.

51. Note, Robinson, 3 October 1967, MH159/220 (TNA).

52. 'Care of the elderly', Hansard HC Deb 11 July 1967, vol 750 cc.431-554.

53. Letters, Matthews and Robb, 29-30 June 1967, MH159/220 (TNA).

54. Letter, Robb to Robinson, 3 July 1967, MH150/350 (TNA).

55. 'Care of the elderly', Hansard HC Deb 11 July 1967, vol 750 cc.431-554.

56. Letter, Robb to Matthews, 19 July 1967, MH159/220 (TNA).

57. Letter, Robb to Robinson, 11 August 1967, MH159/220 (TNA).

58. Letter, Robb to Matthews, 19 July 1967, MH159/220 (TNA).

59. Letter, FDK Williams to Council on Tribunals, 4 August 1967, MH159/ 213 (TNA).

60. Memo, Croft to Hedley, l August 1967, MH159/213 (TNA).

61. Memo, Poole to Hedley, 17 October 1967, MH159/213 (TNA). 
62. Crossman Diaries, March 1969, 178/69/SW (University of Warwick Modern Records Centre, UWMRC).

63. Crossman Diaries, 30 April 1969, CD1162-3 (UWMRC).

64. Letter, Cross to Robinson, 9 June 1967, MH150/350 (TNA).

65. NWMRHB minutes, 17 July 1967, BM.354-5/67 (LMA).

66. Memo, (illegible signature) to Robinson, 4 July 1967, MHl50/350 (TNA).

67. 'Sans Everything (Investigation of Complaints)', Hansard HC Deb 26 July 1967, vol 751 cc.175-176W.

68. See mainly AEGIS files $/ 5 / 6 / 8$.

69. From 'Help - The Community Publications Group', AEGIS/1/3.

70. Letter and photo, Beth Jukes to Robb, 1967, AEGIS/1/3.

71. Tom Arie identified this as his writing.

72. Anon. psychiatrist, interview by author, 2016 .

73. Letter, SK Ruck to Robb, 4 August 1967, AEGIS/1/3.

74. NWMRHB minutes, 17 July 1967, BM.353/67 (LMA).

75. BBCl, 24 Hours, 28 July 1967, transcript, AEGIS/1/6.

76. Letter, France to RHB chairmen, 28 June 1967, MH150/350 (TNA).

77. Stella Brain: Granddaughter of Dr John Langdon-Down who gave his name to 'Down's Syndrome', and married to the neurologist Walter Russell, Baron Brain of Eynsham (Pickering 2004).

78. Stella Brain and Clare Turquet, 'Care of the Elderly in Hospital', SWMRHB, 4 October 1967, MH160/653 (TNA).

79. Letter, Thomas to WHB, 29 August 1967, BD18/816 (TNA).

80. Letter, with statements, Roxan to MoH chief press officer, 26 July 1967, MH150/350 (TNA).

81. Letter, Thomas to WHB, 29 August 1967, BD18/816 (TNA).

82. Memo, MoH press office to Croft, 27 July 1967, MH150/350 (TNA).

83. Storthes Hall HMC minutes with index, 1965-1966, Management of hospital pilfering, 14 October 1965, C416/1/188 (West Yorkshire Archive Service).

84. Comments by Croft about Mr Pantelides statement, received 27 July 1967, MH159/215 (TNA).

85. Memo, MoH press office to Croft, 27 July 1967, MH50/350 (TNA).

86. Visiting book, Ely Hospital HMC, DHE/1/6/1 (Glamorgan Archives, Cardiff).

87. 12 March 1969.

88. Memo, Croft to Hedley, 24 January 1969, MH159/222 (TNA).

89. Letter, André Masters to Barton, 12 December 1970, AEGIS1/10/B.

90. Letter, Barton to Robb, 18 December 1970, AEGIS/1/10/B.

91. Letter, Robb to 'Dearest Sister' (Convent), 1971, AEGIS/1/9/2.

92. See Powick Hospital, Chapter 7, pp. 205-206. 
93. David Enoch, interview by author, 2015.

94. AEGIS meeting, 16 March 1967, 49, Aegis/B/2.

95. Letter, Dennis Hobden to Robb, 25 April 1967, AEGIS/2/3.

96. 'Care of the elderly', Hansard HC Deb 11 July 1967, vol 750 cc.431-554.

97. BBCl, 24 Hours, 28 July 1967, transcript, AEGIS/1/6.

\section{BIBLIOGRAPHY}

Abel-Smith, Brian. 1967. 'Administrative solution: a hospital commissioner?’ 128135. In Robb 1967a.

Administrative Tribunals and Inquiries, Report of Committee. 1957. Cmnd. 218. London: HMSO.

Allen, Anne. 1967. 'One woman who refused to pass by..'. Sunday Mirror, 9 July. Andrews, John. 1967. In 'Public apathy to blame'. Sunday Times, 18 June.

Anon. 1966. 'Old folk'. News of the World, 8 May.

Anon. 1967a. 'Editorial'. Nursing Mirror, 16 June.

Anon. 1967b. 'Report of Board meeting, Oxford RHB'. Oxford Mail, 17 June.

Anon. 1967c. 'First response to last week's editorial'. Nursing Mirror, 23 June.

Anon. 1967d. 'We know such things go on'. Times, 22 July.

Anon. 1967e. 'MP condemns secret inquiry on hospital'. Daily Sketch, 2 October. Anon. 1967f. 'Legal threat on naming hospitals'. Times, 24 October.

Anon. 1967g. 'How long does a confidence stay confidential'. Daily Mirror, 24 October.

Anon. 1967h. 'AEGIS'. Lancet, ii, 85-86.

Anon. 1969. 'Editorial'. Nursing Mirror, 24 January.

Applebey, Mary. 1967. In 'Sans Everything: a misfortune to grow old today'. Sunday Times, 11 June.

Barton, Russell. 1959. Institutional Neurosis. Bristol: John Wright and Sons.

BBC1. 1967. 'What shall we do with granny?'. Scrutiny, 31 March, http:// genome.ch.bbc.co.uk/, accessed 26 September 2016.

Cochrane, David. 1990. 'The AEGIS campaign to improve standards of care in mental hospitals: a case study of the process of social policy change'. PhD thesis, University of London. http://etheses.lse.ac.uk, accessed 17 September 2016.

Crossman, Richard. 1977. The Diaries of a Cabinet Minister, Vol. 3. Secretary of State for Social Services 1968-1970. London: Hamilton and Cape.

Denham, Michael. 2004. 'The history of geriatric medicine and hospital care of the elderly in England between 1929 and the 1970s'. PhD thesis, University College London. http://www.discovery.ucl.ac.uk, accessed 17 September 2016.

DHSS. 1972. Report of the Committee of Inquiry into Whittingham Hospital. Cmnd. 4861. London: HMSO. 
Emery, Ralph. 1967. Understanding Old Age. London: NAMH.

Felstein, Ivor. 1969. Later Life: Geriatrics Today and Tomorrow. Harmondsworth: Penguin Books.

Fine, Wilfred. 1963. 'Care of the elderly disturbed patient'. Lancet, i, 557.

Fortune. John. 1967. 'Hospital management'. Times, 16 May.

Greene, John. 1967. 'Review: Sans Everything'. Nursing Mirror, 30 June.

Hackett, Maurice. 1967. 'Hospitals: we are experts'. Sunday Times, 23 July.

Howe. Geoffrey. 1999. 'The management of public inquiries'. Political Quarterly, 70, 295-304.

Jones, Kathleen and Sidebotham, Roy. 1962. Mental Hospitals at Work. London: Routledge and Kegan Paul.

Joseph, Keith. 1972. 'Foreword' iii-v. In DHSS, 1972.

Julian, Ivor. 1967. In 'Sans Everything: a misfortune to grow old today'. Sunday Times, 11 June.

Leamington Spa reporter. 1967. 'Call for action over crowded hospitals'. Times, 18 March.

Lomax, Montagu. 1921. The Experiences of an Asylum Doctor: With Suggestions for Asylum and Lunacy Law Reform. London: G Allen and Unwin.

Long, Vicky. 2014. Destigmatising Mental Illness? Professional Politics and Public Education in Britain, 1870-1970. Manchester: Manchester University Press.

Mackay, JSB and Ruck, SK. 1967. The Care of the Aged in the Manchester Hospital Board Area. Manchester: RHB.

Mathers, James. 1968. 'Old people in hospital'. BMJ, iii, 374.

Monopolies and Mergers Commission. 1985. United Newspapers PLC and Fleet Holdings PLC, 5-16. http://web.archive.org/web/20070928073311/ http://www.mmc.gov.uk/rep_pub/reports/1985/fulltext/190c02.pdf, accessed 25 September 2016.

NAMH. 1969. Annual Report, 1968-9. London: NAMH.

Northern Correspondent. 1967. 'Disclosures are confirmed'. Times, 20 July.

Pertinax. 1967. 'Without prejudice'. BMJ, i, 755.

Pickering, George. 2004. 'Brain, Walter Russell, first Baron Brain (1895-1966)'. Oxford Dictionary of National Biography. http://www.oxforddnb.com, accessed 4 March 2016.

Press Council. 1966. Press and the People. London: Press Council.

Robb, Barbara. 1967a. Sans Everything: A Case to Answer. London: Nelson.

Robb, Barbara. 1967b. 'Don't let him judge'. Sunday Times, 30 July.

Rogers, Anne and Pilgrim, David. 1996. Mental Health Policy in Britain: A Critical Introduction. Basingstoke: Macmillan Press.

Rogers, Simon. 2011. 'News of the World circulation data: who read it and how many bought it?' Guardian, 8 July.

Rolph, Cecil. 1987. Further Particulars. Oxford: OUP.

Roxan, David. 1958. Sentenced without Cause. London: Muller. 
Roxan, David. 1966. 'Brutality to old folk: it's happening now in some of our hospitals'. News of the World, I May.

Roxan, David. 1967a. "“Old folk beaten in hospital" allegation'. News of the World, 25 June.

Roxan, David. 1967b. 'Heartbreak hospitals'. News of the World, 20 August.

Roxan, David. 1967c. 'I saw patients being treated like dogs'. News of the World, 27 August.

Royal Commission on Tribunals of Inquiry. 1966. Cmnd. 3121. London: HMSO. Russell, Richard. 1967. 'Think on these things. Sans Everything: A Case to Answer. Presented by Barbara Robb'. Tablet, 19 August.

Shearer, Ann. 1976. 'The news media' 109-118. In Changing Patterns of Residential Services for the Mentally Retarded, ed. Robert Kugel and Ann Shearer. Washington, DC: President's Committee on Mental Retardation.

Stewart, Rosemary and Sleeman, Janet. 1967. Continuously under Review: A Study of the Management of Out-patient Departments. London: Bell.

Strabolgi. Beaumont. Heytesbury. Abel-Smith, Brian. Ardizzone, Edward. Harvey, Audrey. Hewetson, John. Robb, Barbara. Sargent, Bill and Woolgar, Daniel. 1965. 'Old people in mental hospitals'. Times, 10 November.

Welsh Office. 1967. Report of the Tribunal Appointed to Inquire into the Disaster at Aberfan on October 21st 1966. HL 316, HC 553. London: HMSO.

Woodford-Williams, Eluned. 1967. 'Misery in our midst'. BMJ, iii, 484-485.

Young, Hugo. 1967. 'The old in hospital'. Sunday Times, 4 June.

Open Access This chapter is licensed under the terms of the Creative Commons Attribution 4.0 International License (http://creativecommons.org/licenses/ by $/ 4.0 /)$, which permits use, sharing, adaptation, distribution and reproduction in any medium or format, as long as you give appropriate credit to the original author(s) and the source, provide a link to the Creative Commons license and indicate if changes were made.

The images or other third party material in this chapter are included in the book's Creative Commons license, unless indicated otherwise in a credit line to the material. If material is not included in the book's Creative Commons license and your intended use is not permitted by statutory regulation or exceeds the permitted use, you will need to obtain permission directly from the copyright holder.

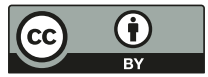

